Acta vet. scand. 1970, 11, 197-208.

From the Department of Pathology, National Veterinary Institute, Stockholm, Sweden.

\title{
A CASE OF GLYCOGENIC CARDIOMEGALY IN A DOG*)
}

\author{
By \\ I. Eldisougi Mostafa $a^{\star \star}$ )
}

This paper describes a rare manifestation of glycogenic cardiomegaly in a dog. Although glycogen storage disease in man was fairly reported on and received due consideration in pediatrics, the rarity of the condition in animals deserves attention. As far as we are aware, the only reference to the disease in animals is clinical observations on a von Gierke-like syndrome in puppies by Bardens et al. (1961) and glycogen storage disease in puppies by Bardens (1966).

The authors in the first reference observed a condition in puppies which clinically resembled the human von Gierke-syndrome; it only differed in the acuteness of symptoms and the response to treatment in spite of the occasional apparent reversibility. The condition was confined to puppies of the toy breeds, between the age of six to twelve weeks. Observations were also made that 88 other cases occurred mostly in five kennels the animals being subjected to stress in one way or another.

The clinical picture followed a definite pattern: depression and muscular tremor, signs of vertigo and incoordination, recession of the eye balls with a sunken appearance of the upper eye

*) This work was accomplished in the Department of Pathology, The National Veterinary Institute, Stockholm, during a SIDA fellowship in 1969.

**) Present address: Department of Veterinary Pathology, University of Khartoum, P. O. Box 32, Khartoum North, Sudan. 
lids, coma, drop of temperature below normal and a decrease of blood sugar to about $40 \mathrm{mg}$ per $100 \mathrm{ml}$ of whole blood (normal $60-100 \mathrm{mg}$ ).

The histopathological studies revealed glycogenic infiltration of the visceral organs. The hepatic cells were enlarged and the sinusoids compressed while the epithelia of renal tubules were swollen and hence a decrease in lumina. Some cases presented excessive glycogen deposits in the myocardium.

In the second reference Bardens reported that the information gathered since his first report on a von Gierke-like syndrome in puppies lead to the belief of three clinically indistinguishable forms of glycogen storage disease in dogs; these were described as a generalized disease, a von Gierke-like syndrome and a Cori's disease (sometimes referred to as limited dextrinosis). Glucagon hydrochloride was used in an attempt to differentiate between these forms. While the first form responded to administration of glucagon and to frequent feeding, the von Gierke-like syndrome was cured by intravenous administration of $5 \%$ dextrose, but frequent relapses and eventual death were not prevented. In the Cori's disease, corticosteroides, dextrose and frequent feedings were thought helpful in the control of the condition.

\section{MATERIAL AND METHODS}

A male dog was sent in from Djursjukhuset, Strömsholm. Necropsy was carried out and tissues were examined bacteriologically, parasitologically and histopathologically. Sections prepared from various formalin-fixed organs were stained with haematoxylin and eosin, van Gieson and PAS methods. Representative sections were incubated in a malt-diastase solution before staining according to the PAS method.

\section{RESULTS}

\section{Clinical findings}

A male Lapland dog, 11/2 year old and weighing $10.3 \mathrm{~kg}$ was submitted to postmortal examination. The animal was reported to have shown ar increasing difficulty in swallowing for half a year; this was accompanied by sporadic vomiting and presence of a copious amount of mucus in the pharynx. The condition was clinically diagnosed as a combination of tonsillitis, oesophageal 
dilatation and myocarditis. Similar cases were reported to have occurred among very small meager dogs, mostly coming from the same kennel.

\section{Morbid anatomy}

The state of nutrition was rather poor.

The spleen and tonsils were enlarged and hyperaemic. The lymph nodes, intestines and stomach were normal; the latter revealed no contents.

The oesophagus was dilated in its lowest part especially in the cardiac portion.

The lungs were oedematous and markedly hyperaemic.

The liver and kidneys showed congestion but no other significant changes.

The rest of the urogenital organs were normal. The joints and brain revealed no lesions. Further examination revealed that the heart was markedly enlarged and weighed $190 \mathrm{~g}$, about three times the normal weight for this age. The hypertrophy was symmetrical and the myocardium appeared fibrous and presented light shreds. The valves, pulmonary artery and aorta were normal.

\section{Histopathology}

Heart. The microscopic picture of the myocardium was characteristic and strikingly confusing; some difficulty was experienced in recognition of the heart sections at the first sight. In sections stained with haematoxylin and eosin, enormous vacuolation of the myocardial cells was revealed (Fig. 1). The cell boundaries were mostly marked by delicately striated or vacuolated rims. Higher magnification revealed an incomplete cytoplasmic meshwork in some of the cells while some others were bulging aside and contained two to three big vacuoles which were separated by thin cytoplasmic walls; still few others, though highly hypertrophic, presented an intact cytoplasm with insignificant meager vacuolation or striation.

The nuclei were comparatively large, rounded or elliptical in shape and mostly situated in the centre of the vacuoles; delicate cytoplasmic shreds connected them with the rest of the cell. They stained faintly in comparison with the interstitial nuclei which revealed more affinity to the basic dyes. The nucleoli were pro- 

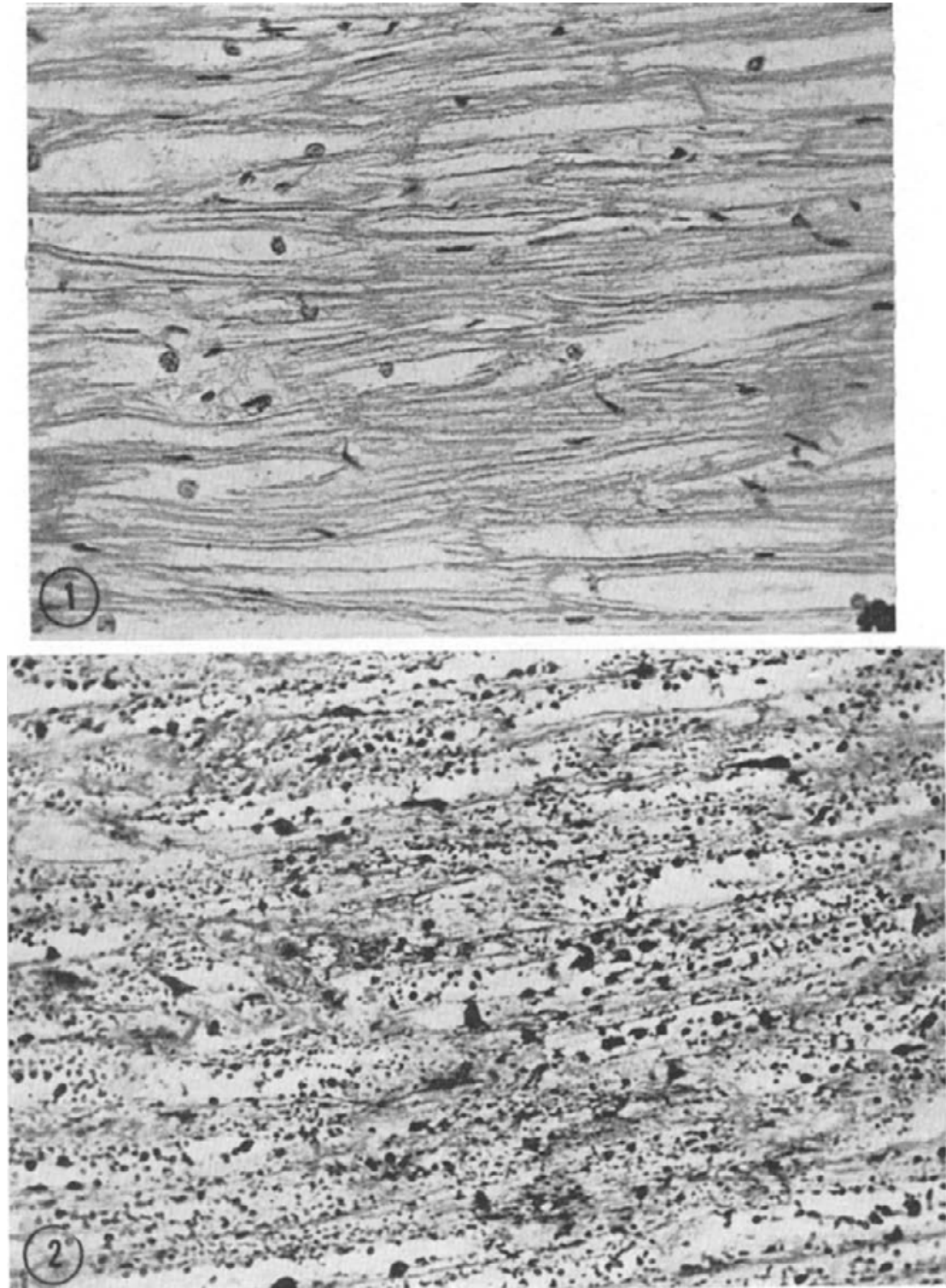

F ig u r e 1. Highly vacuolated myocardial fibres. H \& E. $\times 300$.

Fig u r e 2. Vacuolated myocardium revealing massive glycogenosis. PAS. $\times 300$. 
minent in a faintly stained nuclear core while the periphery of the nuclei stained comparatively better.

A representative amount of glycogen was stainable by the PAS method and was revealed to be diffusely distributed in the different vacuoles. The latter were not completely filled by the glycogen but the unawareness of glycogen presence at time of necropsy and the use of formol saline as a fixative explain this phenomenon (Fig. 2). Nuclear glycogen could not be ascertained with ease.

Liver. The liver was cyanotic and the sinusoids were engorged with blood. Sections stained with haematoxylin and eosin revealed fluffy vascular media and pale foamy hepatic cells. This pattern was diffusely imparted to lobules. Hepatic nuclei were rounded and lightly stained with clear nucleoli and well stained marginal chromatin. A similar picture was well presented in PAS-stained sections which had previously been treated with malt-diastase. The PAS-stained sections themselves showed a considerable amount of glycogen which had not been depleted neither by the wasting of the animal nor by the usage of formol saline as a fixative. The glycogen was mostly conspicuous in the hepatic cytoplasm and as clear glycogenic cuffings in media of arterioles (Fig. 3); fine glycogenic granules were also seen in the inner side of bile ducts. Kupffer cells were free of glycogen.

Kidneys. Apart from congestion, no significant changes were seen. Deposition of glycogen was fairly limited to media of afferent and interlobular arterioles; these could not be missed with the low power as they were intensely surrounded by glycogenic cuffings. Few glycogenic granules were displayed in the loops of Henle and in the straight part of the convoluted tubules.

Pancreas. No glycogenic infiltration was revealed. Islets of Langerhans were scant and few, and brownish pigment was present in the acinar tiscue. Patches of fat necrosis could be recognized despite the spreading areas of postmortal autolytic changes.

Tonsils. These were hyperplastic and congested with clear glycogenic cuffings in media of arterioles.

Oesophagus. In the cardiac portion of the oesophagus, the characteristic feature was that of partial fragmentation, hypertrophy and enormous complete and incomplete vacuolation of both striated and smooth muscle fibers. Some of the muscle fibers were altered beyond recognition and were apparently not 

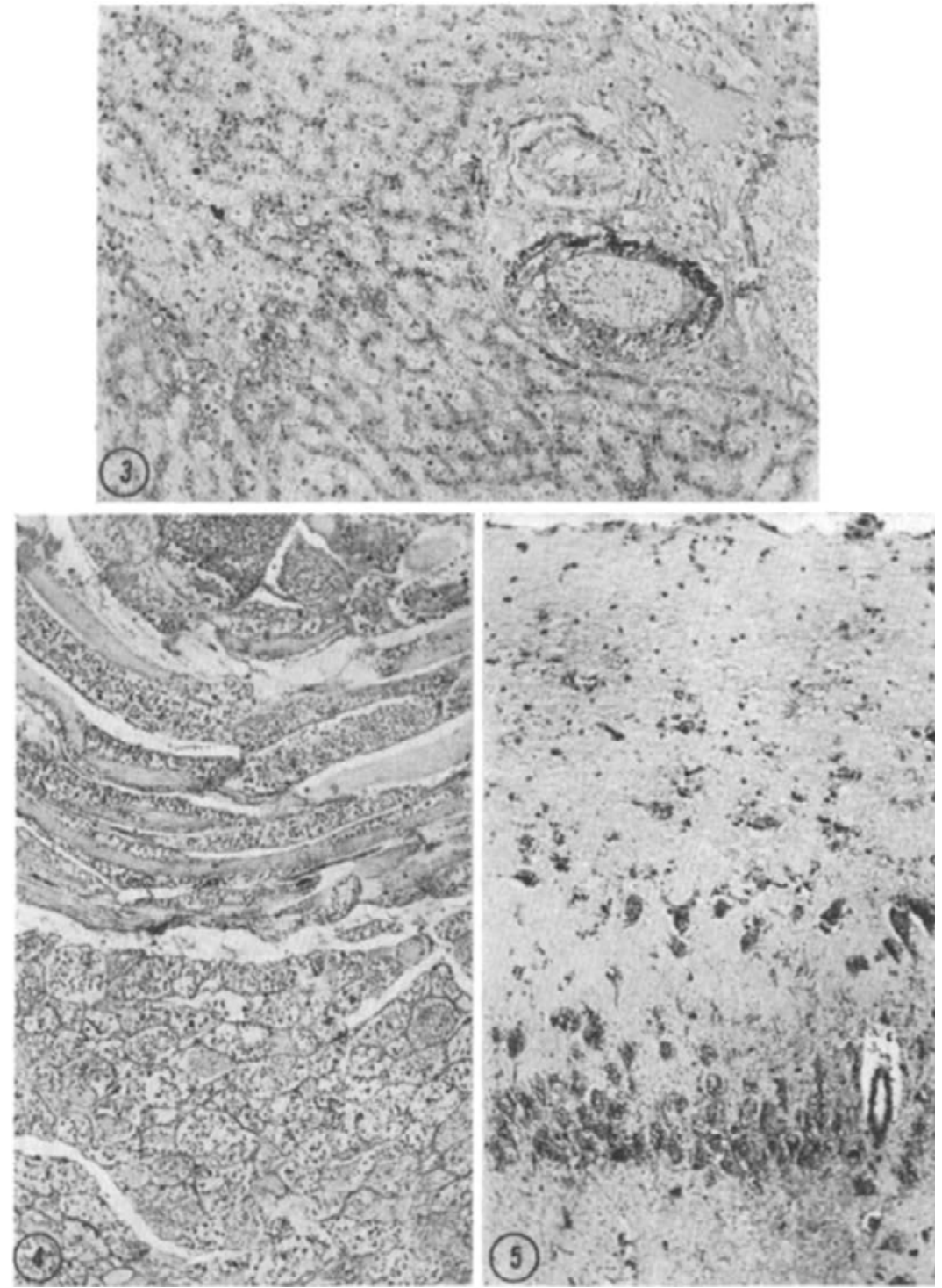

Figure 3. Glycogen in hepatic cells and within the media of a portal artery. PAS. $\times 120$.

Figure 4. Vacuolated oesophageal musculature containing enormous amount of glycogen. PAS. $\times 120$.

F i g u re 5. Considerable glycogenosis of hippocampus. PAS. $\times 120$. 
functioning. An enormous amount of glycogen was revealed within the vacuolated foamy cytoplasm of the muscle fibers; nuclei were mostly intact (Fig. 4). Similar glycogenic deposition was seen in media of vessels.

Lungs. These were mostly congested and oedematous with alternating areas of emphysema and atelectasis which varied from one field to another. Sections stained with haematoxylin and eosin showed granular vacuolation in media of vessels and in the smooth musculature of bronchi and bronchioles. Bronchial mucosa was altered and the lumina filled with a substance swarming with polymorphs and granular macrophages laden with haemosiderin. Hollow areas were seen within the cartilage cells but not in the cartilaginous matrix.

In PAS-stained sections, characteristically laid glycogenic substance was seen around the vessels in tunica media and in the muscular layers of bronchi and bronchioles. Glycogenic granules were also deposited within the alveoli and in the bronchial lumina and the cartilage cells. Few of the PAS-positive granules within the bronchial lumina failed to disappear in sections treated with malt-diastase.

Brain. Considerable amount of glycogen was present in the cerebrum and hippocampus particularly in the cortical and subcortical layers (Fig. 5). The ganglionic and pyramidial cells were highly vacuolated and their cytoplasm revealed copious amounts of glycogen in PAS-stained sections. The presence of glycogen in some of the nuclei was difficult to ascertain. Glycogen was also noticed in the comparatively vacuolated ground substance, in the ventricles and in tunica media of arterioles and capillaries.

The cerebellum presented fairly little amount of glycogen. Deep glycogenic infiltration was only seen in the large ganglionic cells in the brain stem under the cerebellum. Typical glycogenic cuffings were also seen around the vascular media and in the capillaries of the cerebellum and the choroid plexus. Few granules were present in the choroid epithelia themselves.

\section{DISCUSSION}

Apart from clinical observations on a von Gierke-like syndrome in puppies by Bardens et al. (1961) and an attempt for differentiation between the three forms of the disease by Bardens 
(1966), the available literature is devoid of useful data pertaining to animals.

In pediatrics, the disease was first reported by von Gierke in 1929 and Schönheimer in the same year. The former dealt with the clinical and the pathological aspects of a condition in two children which he named as glycogenic hepato-nephromegalia; the latter studied the chemical aspect of one of the cases. Similar cases of von Gierke's syndrome in children have since then aroused interest and were reported successively from different parts by Beumer \& Loeschke (1932), Schall (1932), Unshelm (1932), Bellingham Smith \& O'Flym (1933), Faber (1935), Lindsay et al. (1935), Wilder (1935), Harnapp (1936), Krakower (1936), von Gierke (1937), van Creveld (1939) and others.

A separate type of glycogenic cardiomegaly accompanied with glycogenic infiltration of other organs was similarly reported by various authors such as Pompe (1932), Bischoff (1932), Putschar (1932), Pompe (1933), Kimmelstiel (1933), Antopol et al. (1934), Humphreys \& Kato (1934), Pompe (1936), Esser \& Scheidegger (1937), di Sant'Agnese et al. (1950 a, b), Putschar (1957) and di Sant'Agnese (1959).

The case presented herewith apparently indicates a familial predisposition. It conforms to the one described as glycogenic cardiomegaly and differs both clinically and pathologically from von Gierke's syndrome in children and in animals as described by Bardens et al. The results achieved revealed the presence of massive glycogenic deposition in the heart, brain, liver, lungs, cardiac portion of the oesophagus and media of vessels. To a limited extent, glycogen was also present in the kidneys; pancreas being autolytic and free from glycogen. An interesting pattern of glycogen deposition was characteristically seen in all arterial media, capillaries and in the bronchial and oesophageal musculature; veins being devoid of such a picture. It is unfortunate that the skeletal muscles were not included as it is conceivable that an early diagnostic measure could be served through a glycogen-positive muscular biopsy (Humphreys \& Kato) coupled with the clinical data and an idiopathic cardiac hypertrophy. In the present study, an enormous hypertrophy was only manifested by the heart despite the presence of glycogen in various other organs. This phenomenon in itself merits the name given to the condition in an endeavour of differentiation from other ailments where the heart is involved along with others but not 
hypertrophied. The case constitutes a rare condition which is hereby described for the first time in animals. One agrees fully with di Sant'Agnese et al. (1950 b) that the cardiac type of glycogen storage disease is to be conceived as a separate entity with distinctive clinical, chemical and pathologic manifestations. Unfortunately the criteria thus formulated are not possible to be fulfilled as far as this is considered. Glycogen deposition was only diagnosed in the late stage of histopathology. di Sant'Agnese et al. (1950 a) reported that the brain was normal in their first case and unstained for glycogen in the second one; the heart, liver, kidney and lungs were the only affected organs in the second case which presented a similar picture to the one described hitherto. The involvement of the brain is of a special interest. No major involvement was seen in the cerebellum and hence the abscence of incoordination of movements in the clinical signs. The affected parts as seen in the present case, were mainly the cerebrum, midbrain, brain stem and the Ammon's formation. Glycogenosis of brain was also reported by Kimmelstiel and by Esser \& Scheidegger. The former revealed great amount of glycogen in liver, lymph spaces, heart, sarcolemma of striated muscles and in different parts of the brain; little glycogen was contained in the kidneys. The heart was normal in size while the liver was highly enlarged. Enlarged pancreatic islets were revealed alongside many normal ones.

The involvement of the brain tissue arouses the possibility of impairment of higher nervous functions and responses.

The increased difficulty in swallowing and the sporadic vomiting could similarly be explained bearing in mind the glycogenosis of oesophageal musculature. Some of the muscle fibers were apparently not functioning. Nevertheless, the problem is still open for consideration. In his textbook of pediatrics, Nelson (1964) reported that the affected infant begins, at a few weeks of age, to regress in motor performance, becomes limp, has occasional cyanotic spells and vomits. The aetiology, although it has not so far been elucidated, may be interpreted as an inability to convert the excessive carbohydrate to fat, hence an excessive deposition of glycogen and a poorer state of nutrition. 


\section{REFERENCES}

Antopol, W., J. Heilbrunn \& L. Tochmann: Enlargement of the heart due to abnormal glycogen storage. Amer. J. med. Sci. 1934, 188, $354-359$.

Bardens, J. W.: Glycogen-storage disease in puppies. Vet. Med. small Animal Clin. 1966, 61, 1174-1176.

Bardens, J. W., G. W. Bardens \& B. Bardens: Clinical observations on von Gierke-like syndrome in puppies. Allied Vet. 1961, 4-7.

Bellingham Smith, E. \& E. O'Flym: Familial hepatomegaly of uncertain pathology. Lancet 1933, 11, 297-298.

Beumer, H. \& A. Loeschke: Zum Stoffwechsel bei der Glykogenspeicherkrankheit. (The metabolism of the glycogen-storage disease). Klin. Wschr. 1932, 11, 1824.

Bischoff, G.: Zum klinischen Bild der Glykogenspeicherungskrankheit (Glykogenose). (The clinical picture of the glycogen-storage disease (glycogenosis). Z. Kinderheilk. 1932, 52, 722-726.

Creveld, S. van: Glycogen disease. Medicine (Baltimore) 1939, 18, 1 128.

Esser, M. \& S. Scheidegger: Glycogenkrankheit. (Glycogen-storage disease). Schweiz. med. Wschr. 1937, 67, 970—972.

Faber, V.: Uber die Glykogenkrankheit (Hepatomegalia glycogenica). (On the glycogen-storage disease). Frankfurt. Z. Path. 1935, 47, $443-454$.

Gierke, E. von: Hepatonephromegalia glycogenica (Glykogenspeicherkrankheit der Leber und der Nieren). (Glycogen-storage disease of the liver and the kidney). Beitr. path. Anat. 1929, 82, $497-513$.

Gierke, E. von: Uber Glykogenspeicherungskrankheit. (On the glycogen-storage disease). Beitr. path. Anat. 1937, 99, 369-385.

Harnapp, G. O.: Zur Klinik der Hepatomegalien mit Kohlehydratstoffwechselstörungen. (The clinical picture of hepatomegaly with disturbance of the carbohydrate metabolism).

I. Glykogenspeicherkrankheit. (Glycogen-storage disease).Mschr. Kinderheilk. 1936, 66, 169-183.

II. Fettleber und Cirrhose. (Fatty liver and cirrhosis). Mschr. Kinderheilk. 1936, 66, 184-193.

III. Differentialdiagnose und Pathogenese der Glykogenspeicherungskrankheit. (Differential diagnosis and pathogenesis of glycogen-storage disease). Mschr. Kinderheilk. 1936, 66, 194212.

Humphreys, E. M.\& K. Kato: Glycogen storage disease. Amer. J. Path. 1934, 10, 589-614.

Kimmelstiel. P.: Uber Glykogenose. (On the glycogen-storage disease). Beitr. path. Anat. 1933, 91, 1-19.

Krakower, $C .:$ The lipoid factor in glycogen storage disease. J. Pediat. 1936, 9, 728-743. 
Lindsay, L. M., A. Ross \& F. W. Wigglesworth: von Gierke's glycogen disease. Ann. intern. Med. 1935, 9, 274-282.

Nelson, E. W.: Textbook of Pediatrics. ed. W. B. Saunders Company, London. 8th Ed., 1964, 1191-1192.

Pompe, J. C.: Over idiopathische hypertrophie van het heart. (On idiopathic hypertrophy of the heart). Ned. T. Geneesk. 1932, 76, $304-311$.

Pompe, J. C.: Hypertrophie idiopathique du coeur. (On idiopathic hypertrophy of the heart). Ann. Anat. path. 1933, 10, 23-35.

Pompe, J. C.: Cardiomegalia glycogenica. Thesis. Amsterdam 1936.

Putschar, W.: Uber angeborene Glykogenspeicherkrankheit des Herzens. "Thesaurismosis glycogenica“" (von Gierke). (On congenital glycogen-storage disease of the heart). Beitr. path. Anat. 1932, 90, 222-233.

Putschar, W. G.: Glycogen disease. Milit. Med. 1957, 120, 276-281.

Sant'Agnese, P. A. di: Disease of glycogen storage with special reference to the cardiac type of generalized glycogenosis. Ann. N. Y. Acad. Sci. 1959, 72, 439-450.

Sant'Agnese, P. A. di, I). H. Andersen, H. H. Mason \& W. A. Bauman: Glycogen storage disease of the heart. I. Pediatrics $1950 \mathrm{a}, 6$, $402-424$.

Sant'Agnese, P. A. di, D. H. Andersen \& H. H. Mason: Glycogen storage disease of the heart. II. Pediatrics $1950 \mathrm{~b}, 6,607-623$.

Schall, L.: Drei Fälle von Glykogenspeicherkrankheit (Hepatomegalia glycogenica von Gierke). (Three cases of glycogen-storage disease). Münch. med. Wschr. 1932, 79, 2078-2080.

Schönheimer, R.: Ưber eine eigenartige Störung des Kohlehydratstoffwechsels. (On a peculiar disturbance of the carbohydrate metabolism). Hoppe-Seylers Z. physiol. Chem. 1929, 182, 148-150.

Unshelm, E.: Die Glykogenkrankheit (zugleich ein Beitrag zur Frage des hepatogenen infantilismus). (The glycogen-storage disease (at the same time a contribution to the question of hepatic infantilism)). Jb. Kinderheilk. phys. Erzieh. 1932, 137, 257-302.

Wilder, R. L.: A case of hepatonephromegalia glycogenica (von Gierke's glycogen storage disease). J. Pediat. 1935, 7, 214-219.

\section{SUMMARY}

A description is given of the macroscopic and microscopic picture of a rare entity of glycogenic cardiomegaly in a dog. Clinically it was diagnosed as a combination of tonsillitis, oesophageal dilatation and myocarditis. The characteristic symptoms were increasing difficulty in swallowing, sporadic vomiting, copious amount of mucus in the pharynx, unthriftiness and poor state of nutrition.

The histochemical changes were characteristic, indicated a process of glycogenosis and conformed to the classic form of Pompe's disease. Beside the enormously hypertrophied heart, the process successively involved the brain, liver, lungs, oesophagus and kidneys. 
An interesting diagnostic pattern of glycogenosis was revealed in capillaries and in all arterial media.

The literature on glycogen storage disease is briefly reviewed and critically discussed with reference to the case presented.

\section{SAMMANFATTNING}

Ett fall av cardiomegalia glycogenica hos hund.

Ett sällsynt fall av cardiomegalia glycogenica hos hund beskrives makro- och mikroskopiskt. Fallet diagnosticerades kliniskt som en kombination av tonsillit, eosofagusdilatation och myokardit. Karaktäristiska symtom var ökande sväljningssvårigheter, sporadiska kräkningar, slemansamling i svalget, apati och avmagring. Mikroskopiskt påvisades patologiska glykogenavlagringar överensstämmande med den klassiska formen av Pompes sjukdom. Förutom i det starkt förstorade hjärtat påvisades förändringar i hjärna, lever, lungor, matstrupe och njurar. Diagnostiskt intressanta glycogenavlagringar påvisades i kapillärerna och i median i alla artärer.

Litteraturen över glykogenoser genomgås kortfattat och diskuteras kritiskt med utgångspunkt från det framlagda fallet.

(Received September 19, 1969). 